\title{
Awareness of Solid Waste Management and its Health Issues
}

\author{
Rajkumar P.
}

\begin{abstract}
This research paper focused on awareness about the management of solid waste among the public. The research is descriptive in nature. The study has gone through in Thanjavur District with 240 public as respondents. The researcher adopts a convenience sampling technique. The researcher used factor analysis, multiple regression and One-way anova statistical tools be used to assessed the data using IBM 21 SPSS package. The study result would be the baseline information about solid waste management in the research area. The results would help the municipalities to know the current position also needs of the community concerning solid waste management practices.
\end{abstract}

Index Terms: Awareness, Solid Waste Management, Thanjavur

\section{INTRODUCTION}

Environmental safeguard is very important and necessary for every human being. The waste disposal which is not being proper maintenance cause pollution. Environmental pollution is the source of several diseases to the public. Therefore good condition solid waste management practice is essential in all cities. s significant essential for the management of solid waste. Licy et.al (2013) stated that waste management is a discipline of logistics, societal responsibilities, environmental effect and expenditure of an company waste clearance. Gathering, transportation, and disposal are the fundamental mechanisms of Solid Waste Management. Further the solid waste management has an integrated varied series of activities such as reduction, reprocessing, isolation, alteration, treatment and discarding (Zagozewski et al, 2011). The solid waste management was handled by the municipalities in every city. Moreover the consciousness to solid waste management and its effects among public is essential one. So that people can follow the effective and proper solid waste management techniques. Consequently this research further focused on public consciousness towards solid waste management and health issues.

\section{REVIEW OF LITERATURE}

Essien blessing Stephen (2014) stated that occupational stress Sahu (2007), described that in the severe ecological problems which influence the health of human beings and animals. Sharholy et.al (2008), conclude that giving awareness programs in schools to children and parents may increase the proper practice of solid waste management. The researcher also suggested that the education department also joined up

Revised Manuscript Received on December 15, 2019

Rajkumar P., Professor, Department of Sociology, Madurai Kamaraj University, Madurai, India. with the municipalities for this societal benefited programs for great success.

Ifegbesan (2008) determined the present position of solid waste management in Nigeria. The research findings revealed that the people were more aware of the necessity and significance of the waste management but they were poor in good practicing.

Edlight (2014), studied the solid waste management practice in Zimbabwe. The research results revealed that the public was aware of the need and necessity of proper solid waste management but they were not aware of the reuse, recycle, reduce and rethink. The researcher suggested that the government of Zimbabwe should educate the 4R (reuse, recycle, reduce and rethinking) which leads to effective solid waste management in the city.

Maria (2018) did research on solid waste management among students and parents in Philippines. The results revealed that students were moderately aware of the proper solid waste management. Further the parents in the occupation have knowledge about solid waste management compare to others.

\section{RESEARCH METHODOLOGY}

\section{A. Objectives of the Study}

- To study the awareness of solid waste management in Thanjavur District.

- To determine whether there exist any significant differences between the male and female regarding the environmental awareness of solid waste management.

- To study the impact of improper solid waste management on health effects.

\section{B. Sampling Method and Technique}

A descriptive study was adopted in the research. The convenience sampling technique was followed to collect the data in the interview schedule method. The data were collected through structured questionnaire. A Structured questionnaire was pursued and part of questions taken from the Ajith (2015) "A study on the effectiveness of solid waste management of municipalities in Kerala" doctorate thesis. 240 public people respondents took part in this research.

\section{Source of Data}

The research used both the primary and secondary data for the analysis. The primary data collected from the public people in Thanjavur district using the questionnaire. The secondary data collected from journals, e-books, articles, websites, books, etc. 


\section{Awareness of Solid Waste Management and its Health Issues}

\section{Area of the study}

The Thanjavur District was chosen for the research due to know the current situation of solid waste management in the new recent smart city of Tamilnadu.

\section{E. Statistical Tools}

The research primary data were analyzed through IBM SPSS 21 package. Exploratory Factor Analysis, One-way Anova, and Multiple Regressions statistics were used in the research. Aarthi Dhakshana and Rajandran (2017) have used to determined the impact of independent variables on dependent variables.

\section{F. Variables used in the study}

\section{Independent Variables:}

(i)Awareness towards education about waste management

Demonstration and communal education programs direct to well solid waste management (E1), guidance solid waste to employees and educating public will attract their support for an efficient solid waste management (E2), training campaing about educating solid waste at school is best way to manage the solid waste (E3), demonstrating educating the waste management using multimedia will get less trash (E4),

\section{(ii) Awareness towards environmental impact}

Interment of waste pollute water (Env 1), flaming the waste pollute air (Env 2), inappropriate waste management show the way to water and air contamination which is a severe ecological problem (Env 3), landfill sites and treatment plants adjacent to water body and marshy areas pollutes water (Env 4 ), inappropriate solid waste management is liable for abolition of some species from the world (Env 5), the smell about waste dumps are because of Methane Gas produced from decay of biodegradable waste (Env 6), excess packaging, disposable throw prodcuts, plastic carry bags and pet bottles degrade the environment (Env 7).

\section{(iii) Awareness towards a health problem}

The waste which is throwing out cause the unsanitary circumstances and blockage of drainage which ultimately reason health hazards (HP1), inappropriate management of solid waste is causes for disease like Chikungunya, Dengue etc. (HP2), rodents, animals and birds scavenging through waste dumps spread diseases (HP3), Public who lives close to waste chuck and landfills were suffered from respiratory problems, eye diseases. (HP4),

(iv) Awareness towards various technology on waste management

After isolation the Landfilling of waste have to be done (T1), the hazardous waste and other wastes should not be mix (T2), composting is the best and cheap method to progress the biodegradable waste (T3), vermicomposting which is acquired from biofertilizer to alternate the chemical fertilizers (T4), biogas can be produce from biodegradable waste (T5), Supplement of LPG is biogas (T6). (v) Awareness about consumer consciousness in waste management

While purchase and consumption of the products worried about the waste generation (CC1), During shopping asserting an environmentally friendly reusable packing materials (CC2), of the consicouness of plastic cannot be ruined by on fire (CC3), an idea about anticipation, decline, reprocess, and reprocess is the sequence of main concern to manage non-biodegradable waste such as plastic, glass, paper, metal etc. (CC4).

\section{G. Hypothesis}

- There is no difference between gender and environmental awareness of solid waste management.

- There is no impact on improper waste management on health effects

\section{DATA ANALYSIS AND INTERPRETATION}

\section{A. Socio Categorical Description of the respondents in Thanjavur District}

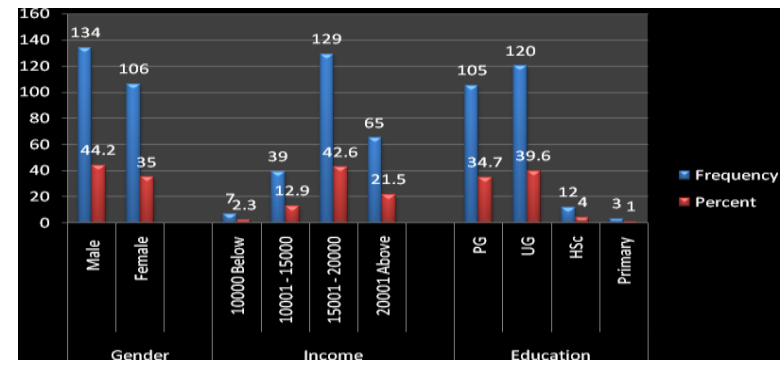

The socio-categorical chart shows that the socio-demographic data of the respondents. It describe that greater part of the respondents were male with (44.2\%) followed by female with $(35 \%)$, the results showed that majority of the respondents attain 15001-20000 income per month with $(42.6 \%)$ followed by $20001 \&$ above with $(21.5 \%), 10001-15000$ wit $(12.9 \%)$ and 10000 below $(2.3 \%)$ respectively. It is apparent that majority $(39.6 \%)$ of the respondents were completed UG followed by PG of $(34.7 \%)$, Higher secondary of $(4 \%)$ and primary education of (1\%).

\section{B. Factor Analysis}

Table 1: KMO and Bartlett's Test

\begin{tabular}{|l|l|l|}
\hline $\begin{array}{l}\text { Kaiser-Meyer-Olkin } \\
\text { Measure of Sampling } \\
\text { Adequacy }\end{array}$ & & 0.834 \\
\hline $\begin{array}{l}\text { Bartlett's Test of } \\
\text { Sphericity }\end{array}$ & Approx. Chi-Square & 3562.00 \\
\hline & df & 300 \\
\hline & Sig. & 0.000 \\
\hline
\end{tabular}

\section{Published By:}


The KMO and Bartlett's Test table exposed that data fitness for factor analysis $(\mathrm{KMO}=0.834)$, with a significant value of $0.000,(3562.00)$. The communalities extraction values should be more than 0.4. Ford (1986) recommended that the value more than 0.4 has meaningful output. Then the pattern matrix club into the factors and the value less than 0.4 is detached from the pattern matrix. The loades items were used for the further study.

Table 2: Total Variance Explained

\begin{tabular}{|c|c|c|c|c|c|c|}
\hline \multirow{2}{*}{$\begin{array}{l}\text { Co } \\
\text { mp } \\
\text { one } \\
\text { nt }\end{array}$} & \multicolumn{3}{|c|}{ Initial Eigen values } & \multirow{2}{*}{$\begin{array}{l}\text { Extractio } \\
\text { n Sums of } \\
\text { Squared } \\
\text { Loadings } \\
\text { Total }\end{array}$} & \multirow{2}{*}{ 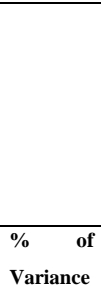 } & \multirow{2}{*}{ 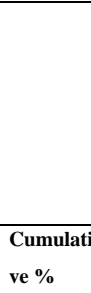 } \\
\hline & Total & $\begin{array}{l}\% \text { of } \\
\text { Variance }\end{array}$ & $\begin{array}{l}\text { Cumulati } \\
\text { ve } \%\end{array}$ & & & \\
\hline 1 & 8.346689 & 33.38676 & 33.38676 & 8.346689 & 33.38676 & 33.38676 \\
\hline 2 & $\begin{array}{l}3.024820 \\
8\end{array}$ & 12.09928 & 45.48604 & 3.024821 & 12.09928 & 45.48604 \\
\hline 3 & 1.881449 & 7.525794 & 53.01183 & 1.881449 & 7.525794 & 53.01183 \\
\hline 4 & 1.449306 & 5.797225 & 58.80906 & 1.449306 & 5.797225 & 58.80906 \\
\hline 5 & 1.253537 & 5.01415 & 63.82321 & 1.253537 & 5.01415 & 63.82321 \\
\hline 6 & 1.066418 & 4.26567 & 68.08888 & & & \\
\hline 7 & 0.964169 & 3.856676 & 71.94555 & & & \\
\hline 8 & 0.849303 & 3.397212 & 75.34277 & & & \\
\hline 9 & 0.804853 & 3.219412 & 78.56218 & & & \\
\hline 10 & 0.68059 & 2.722362 & 81.28454 & & & \\
\hline 11 & 0.624884 & 2.499537 & 83.78408 & & & \\
\hline 12 & 0.594305 & 2.377218 & 86.1613 & & & \\
\hline 13 & 0.47702 & 1.908079 & 88.06937 & & & \\
\hline 14 & 0.43309 & 1.732358 & 89.80173 & & & \\
\hline 15 & 0.364034 & 1.456134 & 91.25787 & & & \\
\hline 16 & 0.340318 & 1.361273 & 92.61914 & & & \\
\hline 17 & 0.302842 & 1.211367 & 93.83051 & & & \\
\hline 18 & 0.274639 & 1.098557 & 94.92906 & & & \\
\hline 19 & 0.237442 & 0.949768 & 95.87883 & & & \\
\hline 20 & 0.210485 & 0.84194 & 96.72077 & & & \\
\hline 21 & 0.196989 & 0.787956 & 97.50873 & & & \\
\hline 22 & 0.169015 & 0.676059 & 98.18479 & & & \\
\hline 23 & 0.163846 & 0.655385 & 98.84017 & & & \\
\hline 24 & 0.156182 & 0.624727 & 99.4649 & & & \\
\hline 25 & 0.133775 & 0.535101 & 100 & & & \\
\hline
\end{tabular}

The principle component analysis extraction method is used in the analysis. The total variance table revealed that the factors were diversified into five major elements, which have been named environmental factor, technology factor, education factor, health problem factor, and consumer consciousness factor, the obtained results from the factor analysis revealed that the five mentioned factors explained $63.82 \%$ of the variation occurs on awareness of solid waste management. The first factor which is named as environmental factor had the most eigenvalue (8.346) and $33.38 \%$ of the total variances. The subsequent second factor is a technical factor included of four items. This factor Eigenvalue is 12.099 explained $45.486 \%$ of the total variances. The third group is environment factor included of four variables. The factor with Eigenvalue 7.525 explained $53.011 \%$ of the total variances of the variables. The next fourth factor is attitude factor, is included of four variables. The factor with Eigenvalue 5.797 explained total variances of $58.809 \%$. The fifth factor is financial factor, is include of two variables. The factor with Eigenvalue 5.014 explained the total variances are $63.823 \%$.

\begin{tabular}{|c|c|c|c|c|c|}
\hline \multicolumn{6}{|c|}{ Pattern Matrix(a) } \\
\hline \multicolumn{6}{|c|}{ Component } \\
\hline & $\begin{array}{l}\text { Environ } \\
\text { mental }\end{array}$ & $\begin{array}{l}\text { Techn } \\
\text { ology }\end{array}$ & $\begin{array}{l}\text { Educa } \\
\text { tion }\end{array}$ & $\begin{array}{l}\text { Health } \\
\text { Problem }\end{array}$ & $\begin{array}{l}\text { Consumer } \\
\text { Consciou } \\
\text { sness }\end{array}$ \\
\hline Env1 & 0.638 & & & & \\
\hline $\mathrm{T} 1$ & & 0.768 & & & \\
\hline E1 & & & 0.686 & & \\
\hline $\mathrm{T} 2$ & & 0.454 & & & \\
\hline $\mathrm{CC} 1$ & & & & & 0.916 \\
\hline Env2 & 0.669 & & & & \\
\hline $\mathrm{CC} 2$ & & & & & 0.698 \\
\hline Env3 & 0.512 & & & & \\
\hline E2 & & & 0.630 & & \\
\hline E3 & & & 0.619 & & \\
\hline Env4 & 0.587 & & & & \\
\hline Env5 & 0.633 & & & & \\
\hline HP1 & & & & 0.963 & \\
\hline HP2 & & & & 0.888 & \\
\hline CC3 & & & & & 0.416 \\
\hline $\mathrm{T} 3$ & & 0.457 & & & \\
\hline $\mathrm{T} 4$ & & 0.890 & & & \\
\hline T5 & & 0.791 & & & \\
\hline T6 & & 0.816 & & & \\
\hline Env6 & 0.674 & & & & \\
\hline HP3 & & & & 0.415 & \\
\hline Env7 & 0.693 & & & & \\
\hline $\mathrm{CC} 4$ & & & & & 0.836 \\
\hline E4 & & & 0.916 & & \\
\hline
\end{tabular}

The table 6 showed that the exploratory factor analysis of solid waste management awareness among public. The factors were loaded more than 0.4 with their pertinent scales. The 25 items of awareness of solid waste management were retained for the advance developments. 
Awareness of Solid Waste Management and its Health Issues

\begin{tabular}{|c|c|c|c|c|c|c|}
\hline \multicolumn{7}{|c|}{ ANOVA } \\
\hline & & $\begin{array}{l}\text { Sum of } \\
\text { Squares }\end{array}$ & df & $\begin{array}{c}\text { Mean } \\
\text { Square }\end{array}$ & $\mathbf{F}$ & $\begin{array}{l}\mathrm{Si} \\
\text { g. }\end{array}$ \\
\hline \multirow{3}{*}{$\begin{array}{l}\mathrm{Q} 1 \\
5\end{array}$} & $\begin{array}{l}\text { Between } \\
\text { Groups }\end{array}$ & 0.372 & 1 & 0.372 & $\begin{array}{c}0.61 \\
6\end{array}$ & $\begin{array}{c}0 . \\
4 \\
3\end{array}$ \\
\hline & $\begin{array}{l}\text { Within } \\
\text { Groups }\end{array}$ & 143.624 & $\begin{array}{c}23 \\
8\end{array}$ & 0.603 & & \\
\hline & Total & 143.996 & 23 & & & \\
\hline \multirow{3}{*}{$\begin{array}{l}\text { Q1 } \\
6\end{array}$} & $\begin{array}{c}\text { Between } \\
\text { Groups }\end{array}$ & 0.309 & 1 & 0.309 & $\begin{array}{c}0.44 \\
3\end{array}$ & $\begin{array}{l}0 . \\
5 \\
0\end{array}$ \\
\hline & $\begin{array}{l}\text { Within } \\
\text { Groups }\end{array}$ & 165.854 & $\begin{array}{c}23 \\
8\end{array}$ & 0.697 & & \\
\hline & Total & 166.162 & $\begin{array}{c}23 \\
9\end{array}$ & & & \\
\hline \multirow{3}{*}{$\begin{array}{l}\text { Q1 } \\
7\end{array}$} & $\begin{array}{l}\text { Between } \\
\text { Groups }\end{array}$ & 3.351 & 1 & 3.351 & $\begin{array}{c}4.79 \\
8\end{array}$ & $\begin{array}{c}0 . \\
0 \\
2\end{array}$ \\
\hline & $\begin{array}{l}\text { Within } \\
\text { Groups }\end{array}$ & 166.232 & $\begin{array}{c}23 \\
8\end{array}$ & 0.698 & & \\
\hline & Total & 169.583 & $\begin{array}{c}23 \\
9\end{array}$ & & & \\
\hline \multirow{3}{*}{$\begin{array}{l}\text { Q1 } \\
8\end{array}$} & $\begin{array}{c}\text { Between } \\
\text { Groups }\end{array}$ & 0.247 & 1 & 0.247 & $\begin{array}{c}0.34 \\
4\end{array}$ & $\begin{array}{l}0 . \\
5 \\
5\end{array}$ \\
\hline & $\begin{array}{l}\text { Within } \\
\text { Groups }\end{array}$ & 171.215 & $\begin{array}{c}23 \\
8\end{array}$ & 0.719 & & \\
\hline & Total & 171.462 & 23 & & & \\
\hline \multirow{3}{*}{$\begin{array}{l}\text { Q1 } \\
9\end{array}$} & $\begin{array}{c}\text { Between } \\
\text { Groups }\end{array}$ & 0.123 & 1 & 0.123 & $\begin{array}{c}0.12 \\
9\end{array}$ & $\begin{array}{l}0 . \\
7 \\
2\end{array}$ \\
\hline & $\begin{array}{l}\text { Within } \\
\text { Groups }\end{array}$ & 227.277 & $\begin{array}{c}23 \\
8\end{array}$ & 0.955 & & \\
\hline & Total & 227.4 & 23 & & & \\
\hline \multirow{3}{*}{$\begin{array}{c}\text { Q2 } \\
0\end{array}$} & $\begin{array}{l}\text { Between } \\
\text { Groups }\end{array}$ & 1.321 & 1 & 1.321 & 3.4 & $\begin{array}{l}0 . \\
0 \\
6\end{array}$ \\
\hline & $\begin{array}{l}\text { Within } \\
\text { Groups }\end{array}$ & 92.475 & $\begin{array}{c}23 \\
8\end{array}$ & 0.389 & & \\
\hline & Total & 93.796 & 23 & & & \\
\hline \multirow{3}{*}{$\begin{array}{c}\mathrm{Q} 2 \\
1\end{array}$} & $\begin{array}{c}\text { Between } \\
\text { Groups }\end{array}$ & 0.006 & 1 & 0.006 & $\begin{array}{c}0.00 \\
9\end{array}$ & $\begin{array}{c}0 . \\
9 \\
2\end{array}$ \\
\hline & $\begin{array}{l}\text { Within } \\
\text { Groups }\end{array}$ & 157.29 & $\begin{array}{c}23 \\
8\end{array}$ & 0.661 & & \\
\hline & Total & 157.296 & 23 & & & \\
\hline
\end{tabular}

One way ANOVA table shows that there is difference between the gender and environmental awareness. Among seven independent variables only one variable that improper waste management show the way to water and air pollution which is a severe environmental problem has a significant difference among the gender and the significant value is 0.029 with the $\mathrm{F}$ value of 4.798 .

\begin{tabular}{|l|r|r|r|r|}
\hline \multicolumn{5}{|c|}{ Model Summary } \\
\hline & \multicolumn{1}{|c|}{ R } & R Square & $\begin{array}{c}\text { Adjusted } \\
\text { R Square }\end{array}$ & $\begin{array}{c}\text { Std. an } \\
\text { error of } \\
\text { the } \\
\text { Estimate }\end{array}$ \\
\hline 1 & $.563^{\mathrm{a}}$ & 0.617 & 0.602 & 0.755 \\
\hline $\begin{array}{l}\text { a. Predictors: (Constant), Viral Fever, Diarrhea, Dengue, Skin infection, } \\
\text { Plague }\end{array}$ \\
\hline \multicolumn{5}{|l}{ b. Dependent Variable: Improper Solid waste management } \\
\hline
\end{tabular}

The model summary table explains that the regression analysis in which adjusted R2 explains how much the improper solid waste management affects the human health. The adjusted R2 value (0.602) showed that $60.2 \%$ affects the human health due to improper solid waste management.

\begin{tabular}{|c|c|c|c|c|c|c|}
\hline \multicolumn{7}{|c|}{ ANOVA $^{b}$} \\
\hline \multicolumn{2}{|c|}{ Model } & $\begin{array}{l}\text { Sum of } \\
\text { Squares }\end{array}$ & df & $\begin{array}{l}\text { Mean } \\
\text { Square }\end{array}$ & $\mathbf{F}$ & Sig. \\
\hline \multirow{3}{*}{1} & Regression & 61.913 & 5 & 12.383 & $\begin{array}{r}21.71 \\
8\end{array}$ & $\begin{array}{r}.000 \\
\mathrm{a}\end{array}$ \\
\hline & Residual & 133.42 & $\begin{array}{r}23 \\
4\end{array}$ & 0.57 & & \\
\hline & Total & 195.333 & $\begin{array}{r}23 \\
9\end{array}$ & & & \\
\hline \multicolumn{7}{|c|}{$\begin{array}{l}\text { a. Predictors: (Constant), Viral Fever, Diarrhea, Dengue, Skin infection, } \\
\text { Plague }\end{array}$} \\
\hline
\end{tabular}

The ANOVA table shows that the significance value is $<0.05$ and $\mathrm{F}=21.718$ that the predictor's independent variables have strong prediction over the dependent variable.

\begin{tabular}{|c|c|c|c|c|c|c|}
\hline \multicolumn{7}{|c|}{ Coefficients } \\
\hline \multirow{2}{*}{\multicolumn{2}{|c|}{ Model }} & \multicolumn{2}{|c|}{$\begin{array}{l}\text { Unstandardized } \\
\text { Coefficients }\end{array}$} & \multirow{2}{*}{$\begin{array}{c}\begin{array}{c}\text { Standardized } \\
\text { Coefficients }\end{array} \\
\text { Beta }\end{array}$} & \multirow[t]{2}{*}{$\mathbf{t}$} & \multirow{2}{*}{ Sig. } \\
\hline & & B & $\begin{array}{c}\text { Std. } \\
\text { Error }\end{array}$ & & & \\
\hline \multirow{6}{*}{1} & (Constant) & 0.231 & 0.406 & & $\begin{array}{c}0.56 \\
8\end{array}$ & 0.57 \\
\hline & $\begin{array}{l}\text { Viral } \\
\text { Fever }\end{array}$ & 0.083 & 0.075 & 0.07 & $\begin{array}{c}1.10 \\
7\end{array}$ & $\begin{array}{c}0.26 \\
9\end{array}$ \\
\hline & Diarrhea & 0.369 & 0.068 & 0.356 & $\begin{array}{c}5.46 \\
3\end{array}$ & 0 \\
\hline & Dengue & 0.262 & 0.069 & 0.224 & $\begin{array}{c}3.81 \\
9\end{array}$ & 0 \\
\hline & $\begin{array}{l}\text { Skin } \\
\text { infection }\end{array}$ & 0.17 & 0.048 & 0.193 & $\begin{array}{c}3.53 \\
9\end{array}$ & 0 \\
\hline & Plague & -0.03 & 0.053 & -0.032 & -0.57 & $\begin{array}{c}0.56 \\
9\end{array}$ \\
\hline
\end{tabular}

Regression Equation: $Y=\beta 0+\beta 2 \times 2+\beta 3 \times 3+\beta 4 \times 4$

The coefficient table shows that how much impact occurs on independent variables due to depended variable. The result shows that Diarrhea, Dengue and skin infection has a significant value less than 0.05 which shows that there is an

Impact due to improper solid waste management. The results further show that diarrhea has more impact among other variables with $\mathrm{B}$ value 0.369 , 
followed by the Dengue and Skin infection with B value $0.262,0.170$ respectively.

\section{CONCLUSION}

The study focused on public awareness about solid waste management at the study area. The study results explored that the greater part of the people were aware of solid waste management but they were not practicing effectively. The researcher found 25 influencing factors of awareness on solid waste management. The awareness factors were analysed and it was clubbed into 5 factors with 25 items of the upcoming valuation towards the research. The awareness factors were education towards solid waste management, environmental awareness, awareness on health issues, awareness about technology and awareness on consumer consciousness. Additionally, this study shows gender opinions about environmental awareness. The One-way ANOVA result shows that a different opinion among gender regarding water and air pollution has serious effect on environmental issues. Further, the study shows that the impact of improper solid waste management and health issues. The result revealed that due to improper solid waste management the people were effects by Diarrhea, dengue and skin infections. Thus the study clearly reveals that the people had awareness about solid waste management and its serious health issues. The municipalities and government should encourage people to do effective solid waste management by practically to attain good results in the study area.

\section{REFERENCES}

1. Ajith, P.S. (2014), "A study on the effectiveness of solid waste management of Municipalities in Kerala". Mahatma Gandhi University.

2. C.D. Licy, Raghavan Vivek, Kamath Saritha, T.K. Anies and C.T. Josphina (2013) "Awareness, Attitude and Practice of School Students towards Household Waste Management", Journal of Environment (2013), Vol. 02(6), pp 147-150.

3. Edlight Mutungwe, Maria Tsvere, Simbarashe Munikwa, Beauty Dondo, Constantino Pedzisai (2014), "A Study of the Level of Awareness and Practices of Solid Waste Management in Chinhoyi, Urban, Zimbabwe, International Journal of Advanced Research in Management and Social Sciences, Vol 3 (9), pp 71 - 79

4. Ford, J. K., R. C. MacCallum, et al. (1986). "The Application of Exploratory Factor-Analysis in Applied- Psychology - a Critical-Review and Analysis" Personnel Psychology Vol 39(2), pp 291-314.

5. Gentil, E., Clavreul, J., and Christensen, T.H. (2009) “Global warming factor of municipal solid waste management in Europe", Journal of Waste Management and Research, Vol 27(9), pp. 850-860.

6. Ifegbesan, A. (2010), "Exploring secondary school students' understanding and practices of waste management in Ogun State, Nigeria", International Journal of Environment and Science Education, Vol 5(2), pp 201-215.

7. J.D. Aarthi Dhakshana and K.V.R. Rajandran (2017), "A Study on challenges faced by the farmers in Direct Marketing, The Rural Business Series”, Indian Journal of Scientific Research, Vol 14 (1), pp 91-97.

8. Maria Digna T Bose (2018), "Level of Awareness and Practice on Solid Waste Management of Students of ASIST", International Journal of Ecology and Conservation, Vol 25 (1)

9. Sahu, A. K. 2007. Present Scenario of Municipal Solid Waste (MSW) Dumping Grounds in India, Proceedings of the International Conference on Sustainable Solid Waste Management, Chennai, India, pp 327-333.

10. Saungweme, M. (2012), “An Integrated waste management approaches as an alternative social waste management strategy for Mbare Township, Zimbabwe", University of Free State: Bloemfontein.
11. Shobeiri, S.M., Omidvar, B., and Prahallada, N.N. (2007), "A Comparative Study of Environmental Awareness among Secondary School Students in Iran and India", International Journal of Environmental Research, Vol 1(1), pp. 28-34.

12. Zagozewski, R., Judd - Henry, I., Nilson, S., and Bharadwaj, L. (2011) Perspectives of past and present waste disposal practices: A community based participatory research project in three Saskatchewan first nations communities, J. Environmental Health Insights, Vol 5, pp 9-20. 